Journal of Social Sciences (COES\&RJ-JSS)

ISSN (E): 2305-9249 ISSN (P): 2305-9494

Publisher: Centre of Excellence for Scientific \& Research Journalism, COES\&RJ LLC

Online Publication Date: $1^{\text {st }}$ July 2015

Online Issue: Volume 4, Number 3, July 2015

http://www.centreofexcellence.net/J/JSS/JSS Mainpage.htm

\title{
DESIGN OF A PROPOSAL FOR IMPROVING THE ORGANIZATIONAL CULTURE BASED ON MANAGERIAL SKILLS. The case of the Institute of Technology Lázaro Cárdenas.
}

José G. Vargas-Hernández, Patricia Calderón Campos, Jesús Rafael García Serna

\begin{abstract}
:
Every day reinforces the theory that education is the fundamental key to the development of a country; an education based on ethical values and principles that allow humans to the harmonious development and provide a better quality of life. This study aims to determine the relationship between management skills with the culture of the organization, this in order to design a proposal for improving the organizational culture at the Institute Technologic de Lazaro Cárdenas, depending on management skills, allowing viable strategies and objectives, for a positive change in the current situation, assuming the management capacity of an organization, this have influence in your culture organizational.
\end{abstract}

Keywords:

Organizational culture, management skills, Institute Technologic.

JEL:

MO, M59

\section{Citation:}

Hernández, José G. Vargas; Campos, Patricia Calderón, González, Serna, Jesús Rafael García (2015); Design of a proposal for improving the organizational culture based on managerial skills. The case of the Institute of Technology Lazaro Cardenas; Journal of Social Sciences (COES\&RJ-JSS), Vol. 4, No. 3, pp:886-885.

http://dx.doi.org/10.17632/9ctfrnw66h.1 


\section{Introduction}

One of the fundamental and crucial pillars in the social and economic development of a state and a country undoubtedly is education, an education based on ethical principles and values that enable the development of new critic generations and academically prepared for the development of productive and economic sectors of countries. Education is an important means of harmonious and sustainable development for a country to be prosperous within a framework of development and prosperity.

The organizational culture in an educational institution, like any other type of organization is considered essential for the harmonious growth of the organization. Given that culture is the same foundation that allows to reach levels of efficiency and effectiveness in achieving goals, this research conducts a detailed analysis of the variables to relate the first organizational culture analysis. The research is original because it is supported based on experiences gained by one of the co-authors through managing developed as director for a period of 14 years, within which participated in different areas of high-level institution, from the head of department up to the sub-direction. Coupled with this is that already she has 21 years of teaching experience as part of that institution.

This research will consist of an analysis of the main dimensions thereby establishing indicators of managerial skills, and organizational culture through application of tools (surveys) applied to management and teaching staff of the institution, continuing a review results, and concluding with the creation of an objective and feasible proposal to allow improvement in the organizational culture of the Technological Institute of Lazaro Cardenas. Once this phase is continuing with the analysis of the information recompiled through surveys, covering what is planted in both general and specific objectives and checking the approach of the hypothesis. Finally, it reaches to the conclusions and recommendations resulting from work and to propose new research.

This research focus on six skills that, in the opinion of the authors, abstract somehow the relevance of observable and habitual behaviors that warrant a successful person in his/her leadership role. These are: knowledge-oriented; leadership, communication, motivation, effective decision making, negotiation and teamwork skills. The proposed improvements developed will impact directly to generate a change in organizational culture of technological Institute, contributing to this by establishing and maintaining a positive, solid, effective culture that manifests through the achievement of institutional goals.

\section{Research Objectives}

The specific objectives are described below. They are derived from the two main variables that make up the overall objective of this research (organizational culture and management skills).

\section{A. General purpose}

The main objective is to design a proposal for improving the organizational culture of the Technological Institute of Lázaro Cárdenas, depending on management skills. 


\section{B. Specific objectives.}

1)Analyze what is the current leadership style in Lazaro Cardenas institute of technology and its influence on organizational values.

2)Determine the influence of teamwork in the attitudes of workers Lazaro Cardenas Institute of Technology.

3)To analyze the influence of motivation on the behavior of workers in the Technological Institute of Lazaro Cardenas.

\section{Background of the problem}

Organizational culture is a topic that has generated interest from the eighties. However, this term has a wide range of perspectives of study that are explained in the first section as a way to approach this concept. The concept of culture is new in their application to business management. It is a new perspective that allows management to understand and improve the organizations. The following concepts that arise have achieved great importance, because they obey a need to understand what happens in an environment and explain why some activities taking place in organizations fail and others do not.

\section{A. Organizational culture}

The organizational culture has been understood as essential factor to the development of organizations through the behavior of their human beings. It is essential for the efficient and effective development of an enterprise, performance and skills of workers undoubtedly is essential for the organization to achieve growth through the establishment of a strong and sustained culture of all members of the organization.

Organizational culture is one of the fundamental pillars to support those organizations that want to be competitive. The study of organizational culture is a relatively new global phenomenon; noting that two decades ago were few authors related this issue. The first works spread about terms such as values, beliefs, basic assumptions, principles; and others immediately linked as constituting a concept that began to take root in the business field. There is no inherent organizational culture that identifies, distinguishes and orients their actions and ways of doing, ruling their perceptions and their public image with it. Cultural events are themselves categories of analysis, through which you can carry out the cultural diagnosis in a company.

According to Gordon (1997), organizational culture is a system of shared set of values, beliefs and habits within the organization that interact with the formal structure to produce norms of behavior. From the perspective of Gordon organizational culture is stablished to any company or instruction as a set of interconnected actions where in all that drives the organization. This is supported by individual actions that are interleaved together to look like a common system.

One of the most referenced and possibly accepted definitions of organizational culture is the one from Schein (1988, p. 25): A model of basic assumptions invented, discovered or developed by a given group as the members learn to cope with their problems of external adaptation and internal integration, having exercised enough influence to be considered valid and, therefore, to be taught to new members as the correct 
way to perceive, think and feel those problems. The elements of culture and relationships create a unique pattern that distinguishes an organization such as the individual's personality is unique.

As in the classification of people who have characteristics in common, in the case of organizational culture is possible to describe various types of culture (Hellregel, Jackson and Slocum, 2002 p. 602). Such as the authors explain, organizational culture stablishes a number of unique patterns of identity to the organization. As well as people are part of their personal characteristics and internal values, they are built over time. Organizational culture is a series of symbols, ceremonies and myths that the staff communicates to the company's values and deepest beliefs within the organization. These rituals materialize what would be vague and abstract ideas, making them come to life and meaning (Ouchi, 1981).

Organizational culture is a model of basic assumptions invented, discovered or developed by a given group as they learn to cope with their problems of external and internal adaptation, which have carried enough clout to be considered valid and, therefore, be taught to new members as the correct way to perceive, think and feel those problems (Schein, 1988). To Hofstede (1991) is a collective mental programming that distinguishes the members of one group or category of another. It is shared by people whose survival is within the same social environment where it was learned.

\section{B. Management skills.}

Another factor to consider is managerial capabilities seen as the skills that are observable and habitual behaviors that enable the success of a person in its activity or function. The powers are objective in that they have external consequences, but are also subjective in that the perception of them depends on the observer. It does not happen this way with the objectives that are measurable and independent of the person who is measuring. Therefore, the process of assessment of competencies requires more careful assessment of the objective, because it has to take into account its subjectivity.

It may be noted that, traditionally, organizations, whether governmental, educational, industrial or medical, have been managed by a hierarchical distribution of power. Most of the criticisms focus towards the exercise of managerial activity; not question the legitimacy of managers, but the lack of selection processes, recruitment and evaluation to ensure the effectiveness of their daily work, because without doubt, the exercise of leadership is learned in the development of the function. Therefore, rather than a simple exercise in the early months, is a source of frustration for people who make up the organization. Management as an executive function is to guide and coordinate to deliver results (Torres, 2003 p.33).

Hence the importance of developing the capabilities of managers is also related to the development of managerial skills of the different actors of educational institutions (assistant principals, academic directors, research directors, coordinators of different areas, faculty, staff and general support as well as students receiving educational services) due to efficient management is only taken into conformation with an honest and competent team that contributes to achieving the objectives and organizational goals. When this does not occurs, the environment of management becomes complex. A manager is a leader, or a 
person who should be perceived as an authority figure in a situation, it is sure enough of himself and his relationship with others so that experiences a basic trust in the ability of others to think for themselves, to learn for themselves.

From this perspective, and understanding that executive competencies in global scenarios form the axis or center of these five skills, they will be developed in the following sections the meaning and scope of each of the aforementioned managerial attributes (or soft skills), understanding that each competition is part and helps develop management skills necessary for global scenarios presented in a conceptual model that allows understanding of the entire set of analysis with a more systemic approach (Villareal, 2008). Not always the skills and / or abilities have earned the same relative importance in the investigation.

Until recently, the knowledge and most importantly, the mastery of information are essentially valued to the point that represented $75 \%$ of professional valuation. Today, both only represent 20 to $25 \%$ (Villa, 2007), diversifying this valuation as varied as skills to search for information, teamwork, educational leadership, self-learning, among others. The competition would then be the social construction of meaningful and useful for management learning performance, obtained largely through experiential learning (Villareal Julian Puga, 2008).

Management learning performance is evaluated within the object of study as precisely the current organizational culture of the Technological Institute of Lázaro Cárdenas. Subjects to investigate are the principals and teachers who belong to that organization. Two important aspects are addressed, such as organizational culture and managerial skills by establishing a proposal for improvement. The Technological Institute of Lázaro Cárdenas (ITLAC), born from the prevailing need for an institution of higher education in the town in 1987, currently offer 8 races at the undergraduate level, has an enrollment of 2,898 students and A total of 153 staffing consists of 23 directors, 91 teachers and 40 support workers to education.

The Technological Institute of Lázaro Cárdenas (ITLAC) was born from the prevailing need for an institution of higher education in the town in 1987. Currently offer 8 careers at the undergraduate level, with an enrollment of 2,898 students and a total of 153 staffing which consists of 23 directors, 91 teachers and 40 support workers to education. The Institute is located as part of the dependent organizational structure of the National System of Technological Institutes, recently named National Institute of Mexico.

The Technological Institute of Lázaro Cárdenas is considered the No. 2 in the State of Michoacán according to its indicators. It is located in the port of Lazaro Cardenas, the country's main port and one of the largest in Latin America. However, despite the characteristics of its location on a highly productive development pole, this has not achieved the level of development that could aspire given the competitive advantages that the region presents. This is for a lack of work culture presented at the Institution. Not only there is no teamwork established, but also the motivation of its employees is low, plus there is a poor formal communication within the structures that make up the areas and departments. 
In 2004, it was launched the quality program with the work of certification ISO 9000 , achieving to reach it in 2006. This certification was stated the quality system as part of a new philosophy, through management values and principles of quality improvement within each system each semester applies generally to all areas of the institution normatively a survey of labor environment. The results usually establish a lack of teamwork, lack of motivation exists for workers, and the processes of communication and negotiation are not adequate. These results are disclosed and a series of awareness courses are set in their most only cover a necessary indicator for the system, without achieving any improvement in the organizational environment, given that only some attending by indication under a commission.

Every six years the Program for Innovation and Development of the Institute is stablished as a policy document where all strategic planning for achieving annual goals and objectives. This planning document includes a section that sets out the principles governing the institution, values and indicators of growth and development. However, it only works in meeting goals, scope to meet, without generating an improvement in the institutional culture. They are not connected each other. These efforts to improve the culture through various strategies implemented so far by the institution can be considered as isolated efforts and not systemic where they give continuity and improvements are known, through monitoring and feedback to know its scope.

This is that there is no a planned inner change even more alarming is that at the level of Technological Institutes member of Institute of Technology of México are working individually and do not have a specific plan to improve national culture. This should be considered as an institutional change improving organizational culture is a change effort set not only by managers but by all the people within the organization, highlighting that this problem is not determined by people but for the lack of structure in the process, and a new philosophy. For the above this research is presented with the aim of establishing an improvement of organizational culture with the responsibility and participation of the entire institution.

The improvement is then determined depending on the managerial capabilities based on the premise that leaders can generate changes and that these are possessed in an area of control and significant influence within the formal structure of the institution, and therefore through them is that are set the plans and programs of work and philosophy that aims to achieve the goals, because it is considered that the example whereas trails.

\section{Definition of the problem}

\section{A. The object of study}

Based on these arguments, the research problem directly references to the relationship with the managerial capabilities in creating an organizational culture. In this specific case, this is related to an institution of higher education. The object of study is the directive and academic personnel from Technological Institute of Lázaro Cárdenas, where is considered the relationship of organizational culture to be addressed by the staff management skills. The object of research is 23 managers and 91 teachers from 8 different careers offered at the Technological Institute of Lázaro Cárdenas, as shown in Table 1. 
Table 1. Institution: Technological Institute of Lázaro Cárdenas

\begin{tabular}{|l|l|l|l|}
\hline Level & $\begin{array}{l}\text { Managerial/ } \\
\text { Academic }\end{array}$ & $\begin{array}{l}\text { Number of } \\
\text { officials }\end{array}$ & total \\
\hline Direction & Directing & 1 (one) & 1 \\
\hline Sub-directions & Officials & 3 (three) & 3 \\
\hline Chair of departments & $\begin{array}{l}\text { Head of } \\
\text { departments }\end{array}$ & 23 (veintitrés) & 23 \\
\hline 6 careers & Teachers & $\begin{array}{c}91 \quad \text { (Ninety } \\
\text { one) }\end{array}$ & 91 \\
\hline & Total & 118 \\
\hline
\end{tabular}

Source: Prepared

Spatial delimitation: Senior Staff and Teachers of Technological Institute of Lázaro Cárdenas.

Temporal delimitation: Research conducted from 4 August 2014 to October 2015.

\section{Justification}

The Technological Institute of Lázaro Cárdenas is 27 years old. Up to now, it has a culture already developed and entrenched in its ways of working. However this has not been favorable since currently the institution is still in development level and has not been placed in the level of consolidation despite that by the geographical location in which it is located, it should be more prominent. The Institute is located in a privileged area on a major pole of development at national and international level given that currently the port is considered the most important of Mexico and Latin America for its characteristics and commercial development in both import and export products.

This should have already placed the institution at its highest level since it has established agreements with various national and international companies. It could develop joint collaborative projects towards scientific and technological development. Unfortunately the institution does not have a work culture that allows growing both in human, technological and financial resources. Why not? This is due to the lack of an organizational culture well supported on principles and values that generate various sources of growth and change. Attempts have been made such as awareness courses, it is certified in ISO 9000, ISO 14000, inter sectorial programs of courses etc. are established. However, it has not achieved that status of work in teams, because they are lacking motivation, effective communication is not achieved, the leadership in most areas is autocratic type.

The purpose of this paper is to describe the culture from its essence, analyzing the organizational and corporate culture, management skills and their impact to organizational culture. The methodology used is the development of this project based on an analysis of the aforementioned issues and a final analysis where the importance of managerial skills for establishing an organizational culture and its transformation through these is determined by establishing a direct connection between the two variables, same as once 
studied and defined leading to a series of conclusions that will design a proposal to improve organizational culture based on management skills.

The importance of this research lies mainly in solving problems of leadership, communication, motivational, teamwork, negotiation, effective decision making. This research is intended to contribute to the solution of the following problem.

A.The importance of improving the work environment through this proposal would increase productivity, improve communication, teamwork, and aims to create a participatory leadership through changed attitudes and behavior.

B.Have people motivated through the generation or setting values and changing attitudes. This proposal improves greatly contribute to a public higher education institution may be growing.

C.In addition, this proposal may be transferable and applicable to other institutions within any educational institution that are part of the Technological Institutes of Mexico.

D.Similarly this proposal may be transferable to apply to other public institutions with similar characteristics of Mexico.

An analysis of the criteria for justification in Table 2.

Tabla 2. Justification criteria

\begin{tabular}{|l|l|}
\hline Importance & $\begin{array}{l}\text { Given that organizational culture is essential for the harmonious } \\
\text { development of this and generates growth is important to know }\end{array}$ \\
\hline Practical contribution & $\begin{array}{l}\text { The investigation will feature a proposal to develop practical actions that } \\
\text { lead to improved organizational culture in the object of study. }\end{array}$ \\
\hline Theoretical research & $\begin{array}{l}\text { Research deeps in the study of the theories related to the organizational } \\
\text { culture and management skills within public institutions of higher } \\
\text { education. }\end{array}$ \\
\hline Practical contribution & $\begin{array}{l}\text { The research analyzes the problems that occurs in organizations by the } \\
\text { lack of a culture and proposes a strategy for improvement in terms of } \\
\text { management skills. }\end{array}$ \\
\hline Feasibility & $\begin{array}{l}\text { The study is feasible since not refer to economic resources, to be able to } \\
\text { develop. Surveys also given from the study will be applied in the } \\
\text { institution where he currently works at. }\end{array}$ \\
\hline Impact and benefits & $\begin{array}{l}\text { Having strategies of cultural improvement to increase cultural indicators } \\
\text { of growth and development of institutions of higher education. }\end{array}$ \\
\hline
\end{tabular}

Source: Prepared 


\section{Hypothesis}

\section{A. General Hypothesis}

Working Hypotheses: $\mathrm{H} 0=\mathrm{X} 0$

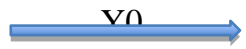

The management skills of an organization influence its organizational culture.

\section{B. Specific Hypothesis}

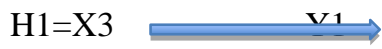

Leadership styles influence organizational values

$\mathrm{H} 2=\mathrm{X} 4$

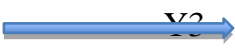

The attitudes of workers determine teamwork

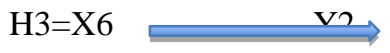

The motivation influence the behavior of workers

\section{Conceptual - Theoretical framework}

\section{A. Concepts of managerial skill and ability.}

The word skill by itself refers to the ability, grace and skill to run something (Guthie Knapp, 2007). The word ability itself refers to capacity, grace and skill to run something Management skills are the new paradigm in both education and employment practice that help to achieve higher performance because it has proven its effectiveness for purposes of training, professional development and evaluation. When it is brought to the skills in plural, they are the same that are linked to a task, involving an environment, are shown in the tasks regularly and effectively, and above all, are learned. The skills are cultivated and educated (Torres, 1998). These are part of the leadership of the great managers and undertake a personal and professional effort.

Therefore, skill is the ability of a person, acquired by learning, capable of producing results provided with maximum accuracy, with minimal time and distended with maximum economy and safety. For purposes of the directive skill, Knapp (2007) notes that skill is the ability of the individual acquired by learning, capable of producing provided with maximum accuracy results, distended with minimal time and with maximum economy and security._ Within the business world, managerial skills are known as all the qualities needed by the managers to manage their own lives and relationships with others. These are part of the leadership of the great managers and undertake a personal and professional effort. 
Among the qualities that are often referred to as directive or managerial skills are often found leadership skills, ability to work in teams, the skills to motivate people around persons, the ability to communicate with employees and the public, speaking, written communication techniques and skills to interact with people. These aspects can be added to the need for a critical view, a good image to the team and a high capacity for innovation.

Ability is defined by Alvarez (1999) as the content dimension showing the behavior of man in a branch of knowledge proper to the culture of humanity. It is, from the psychological point of view, the system of actions and operations dominated by the subject that responds to an objective. Therefore, it is understood that the skills are linked to a specific task, involving a relationship with the environment, are shown in the task performance regularly and effectively, are learned.

Management skills are those technical skills and personal skills that managers, regardless of their area, need to function professionally and adopt aimed behaviors at achieving the best possible contribution of self and others for the purposes of the company and successfully manage the behaviors relationships with others, the direction of other people or employees and the environment (Whetten \& Cameron, 2005 p.76). Management skills are fundamentally the forms of action of leaders that are directly related to their daily work, the same that allow them to function in the performance of their duties. Management skills are all those action capabilities that managers have in driving the organization.

There have been several studies on the influence of managerial skills on fundamental aspects of growth and development of organizations. One of them specifically is about the organizational climate. This research developed by Aburto Hugo Pineda, determined that the leadership, communication, motivation, conflict management and team building variables are directly linked to climate and organizational culture.

\section{1)Concept of culture}

Culture is the set of values, customs, beliefs and practices that contribute to the lifestyle of a specific group (Eagleton, 2001). Other authors like Spradley \& McCurdy, define culture as the knowledge gained that people use to interpret experience and generate behaviors. By the above said, culture determines human behavior through personal experiences according to their birth, the values with which it has grown, beliefs and all the knowledge acquired through time. Edward T. Hall proposes that culture is like an iceberg, since the internal culture encompasses the behavior, beliefs and values of our own culture, in itself it determines if the internal culture or cultures motivates behavior by focusing more on feelings and ideas and that foreign culture is interacting and conflicts with own culture and can be acquired through observation, education or training, is easy to learn and to change e. g. customs, food and language.

Consequently if the internal culture motivates behavior and develops the values, an individual may develop an internal change through new experiences and improving his education, his behavior will change as the environment becomes. 


\section{1)Organizational culture.}

The concept of culture applied to the organization started developing the contribution of the school of human relations, when starting from the experiments conducted by Elton Mayo (1972); it is beginning to recognize the subjective and informal aspects of organizational reality. Mayo (1972) became interested in inquiring about the factors that affect worker performance, concluding that the environment of the group to which the individual belongs significantly affects the perception that this is about the objective aspects of the organization.

As regards the organizations, culture is the general guide behavior, shared beliefs and values that members have in common (Shein, 1992). As stated by Shein, organizational culture largely establishes a fundamental pillar to the growth and development of the same. Bower (1995) states that culture is an invisible element for people who belong to organizations, this is to the point of becoming, sometimes in the way of doing things. However, at the root of every culture are the values on which the organization is based, which may be permanent and last many decades or may change rapidly as a result of time.

Likewise, Stoner (1996) conceptualizes organizational culture as a number of important understandings such as norms, values, attitudes and beliefs shared by members of the organization. Organizational culture forms attitudes among employees and determines how the organization interacts with its environment. Similarly, Robbins (2004) designates organizational culture as a system of common meanings among members that distinguishes one organization from others, where shared values are preserved and shared. Gordon (1997) conceives of organizational culture as a shared system of values, beliefs and habits within the organization that interact with the formal structure to produce behavioral norms.

Mendoza Hernández and Salazar, mentioned that organizational culture is what identifies an organization which promotes among its members a sense of belonging, to profess their own values, beliefs, rules, procedures, standards and language. They also refer to organizational culture as learned and it is a response to the environment by adapting to different situations that arise because companies do not have the ability to control the external environment, but to adapt, with the organizational culture a mechanism used for this.

\section{Contextual framework}

\section{A.Technological Institute of Mexico}

The Technological Institute of Mexico, formerly the National System of Higher Education Technology with 216 institutions distributed throughout Mexico, offers Mexicans the possibility of college-level education, professionalizing the graduates of these Institutions that will answer the requirements of local and regional labor field mainly where they are located in their regions.

On July 23, 2014, it was published in the Official Journal of the Federation, Presidential Decree by which the National Technology of Mexico (TecNM), agency of the 
Ministry of Public Education (SEP) was established, which replaces the administrative unit called Directorate General of Higher Education Technology (DGEST) under the own SEP, and who coordinated the National System of Technological Institutes (SNIT), the largest technological higher education subsystem in the country. Thus, the TecNM by nature is a decentralized organism, offers technical, academic and managerial autonomy, and the ability to coordinate functions, the substantive work and complementary activities attended by the DGEST through technological institutes and research, teaching and development of educational technologies in terms of the decree of creation.

With these powers of nature, TecNM has key objectives set according law fractions that extend the content of Article 2 of the Decree quoted. These objectives are to provide, to develop, coordinate and guide service technology, secular and free higher education in levels of higher technical college, undergraduate and graduate, in the school modality, in-school -a distance- and mixed. These objectives are set in order to develop professionals and researchers suitable for the application and generation of knowledge with a broad culture, sufficient skills and problem solving skills, critical thinking, ethical sense, entrepreneurship, creativity and innovation capacity and able to incorporate scientific and technologically contribute to the development of the sectors of the regional and national context.

The TecNM has the commitment and institutional obligation to design and establish programs to meet the dual education model, focused not only to facilitate and promote academic learning. Also by way of incorporating students to the working life and production processes of enterprises, with the academic supervision of the teachers of TecNM own professional coordination of company assets staff.

At the end of 2012, the Directorate General of Higher Education Technology (DGEST) now National-technological in Mexico, coordinated operation of 262 institutions located in 31 states and the Federal District (See Figure 1). Of these institutions, 126 are federal technological, 130 decentralized and six technological research and development centers. Of the total, 229 with industrial vocation, 20 focused on agricultural sciences, six marine sciences and 1 in the forestry field._The research and development centers are the National Center for Research and Technological Development (CENIDET), the Interdisciplinary Center for Research and Teaching in Technical Education (CIIDET) and four Regional Centers of Optimization and Development Team (CRODE). Figure 1 


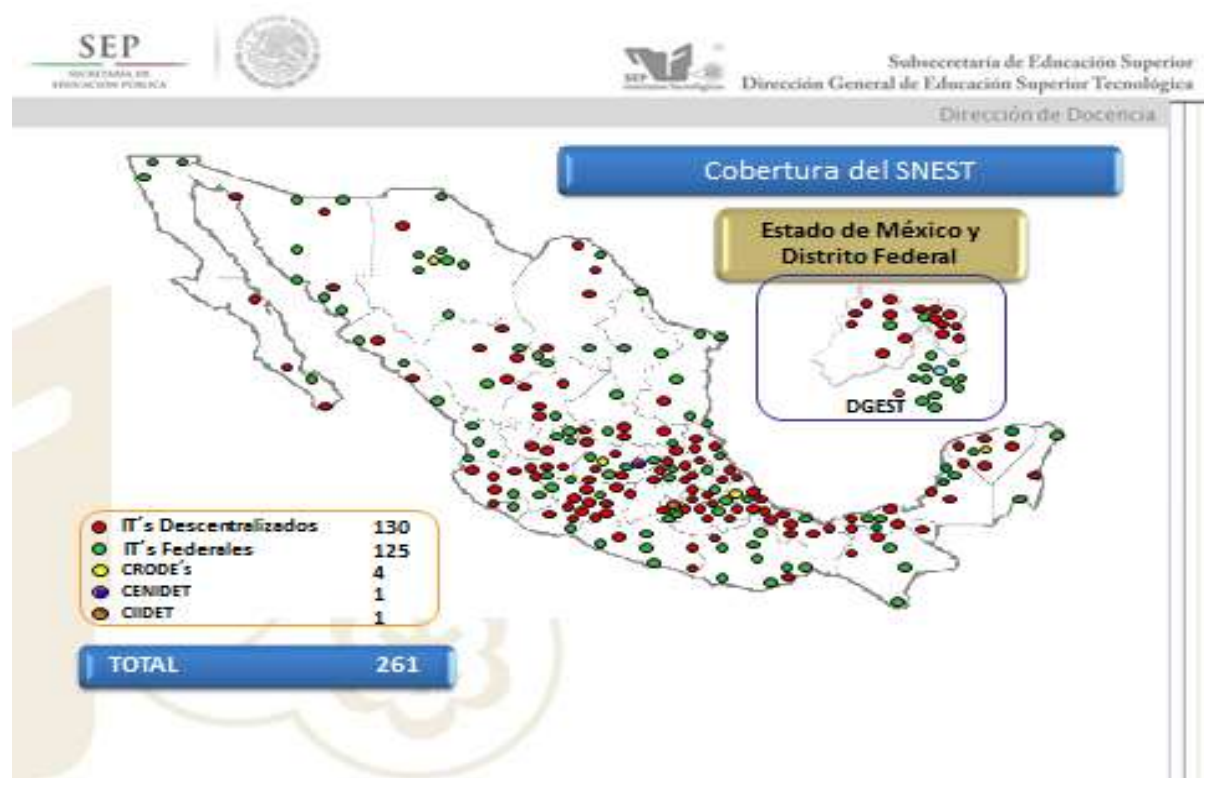

Figure 1 Source: Institutional Innovation and Development Program of TcMX.

\section{Technological Institute of Lázaro Cárdenas.}

The Technological Institute of Lázaro Cárdenas, higher education institution belonging to the National System of Higher Education Technology "SNEST" coordinated by the Directorate General of Higher Education Technology "DGEST" located in the City and Port of Lazaro Cardenas, Michoacán. It is available as an offer of 08 educational careers at bachelor level, out of which 06 are in area of engineering and 02 in the area of Economic and Administrative Sciences.

These 8 careers have the authorization of the Plans and Programs of Study by the Ministry of Public Education and issued by the General Directorate of Technical Education careers that currently offer are; Computer systems engineering, industrial engineering, chemistry engineering, business management engineering, electronic engineering, electromechanical engineering and degrees in administration and public accountant.

The staff that meets the managerial and teaching functions consists of 118 workers with 118 seats and tenure distributed as follows shown on Table 1 and Table 2 and Figure 2. 
Journal of Social Sciences (COES\&RJ-JSS), 4(3), pp. 901-918

Table 3. Total teachers and tenures

\begin{tabular}{|lllll|}
\hline Full time & $3 / 4$ of time & $\begin{array}{l}1 / 2 \text { partial } \\
\text { time }\end{array}$ & $\begin{array}{l}\text { TOTAL } \\
\text { TENURES }\end{array}$ \\
\hline 50 & 4 & 9 & 55 & 118 \\
\hline
\end{tabular}

Source: Own elaboration with data from CIIES Diagnostic ITLAC

Table 4. Teacher tenures and type

$\begin{array}{lc}\text { Teachers with tenure } & \text { Quantity } \\ \text { E38 Full time (40 HRS.) } & 50 \\ \text { E37 "3/4 of time" (30 HRS.) } & 4 \\ \text { E36 "1/2 time" (20 HRS.) } & 9 \\ \text { E35 "Course" (1-19 HRS.) } & 55 \\ \text { TOTAL } & 118\end{array}$

Source: Own elaboration with data from CIIES Diagnostic ITLAC

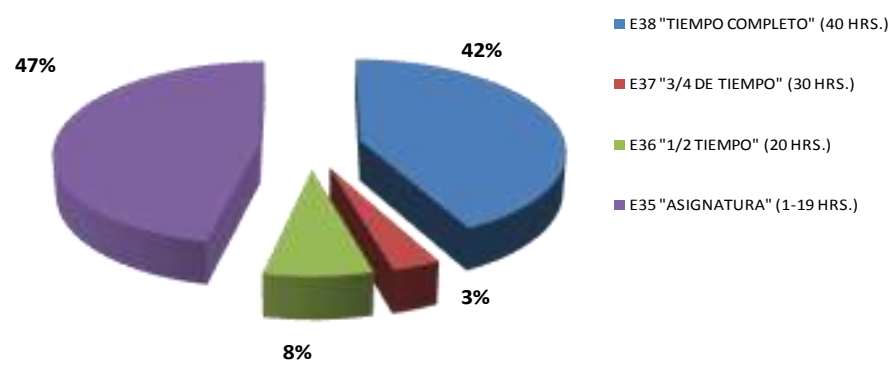

Figure 2. Distribution of teachers by type of tenure Source: Human Resources Management of the ILAC.

\section{Method}

Once it has been completed the review of the theoretical framework and revised the referential framework, the study continues with the description of the methodological strategy in which this research. Likewise, the study is based on detailed description of how was conceived the design and how will be implemented the instruments for obtaining results. The methods used for the development of this research will be presented, highlighting that the generation of knowledge through the completion of an investigation, it is required the application of a design methodology which ensures a logical, systematic and coherent way, through the use of processes, methods and techniques for achieving the objectives, in this regard, according to (Balestrini, 2001).

In the present investigation the mixed method is used to obtain a more complete understanding and analysis of the variables under study, management skills and 
organizational culture. Each variable is measured independently; applying surveys to determine the managerial skills that prevail in the directors of the institution, as well as surveys are applied to employees (teachers) for their perception who have the managerial skills of their leaders (managers). Then, with the information obtained, correlating the variables management skills and organizational culture, with the purpose of determining

\begin{tabular}{|c|c|c|c|c|c|c|}
\hline $\begin{array}{l}\text { Tittle } \\
\text { research }\end{array}$ & $\begin{array}{l}\text { General } \\
\text { question }\end{array}$ & $\begin{array}{l}\text { Specific } \\
\text { questions }\end{array}$ & $\begin{array}{l}\text { General } \\
\text { hypothesis }\end{array}$ & $\begin{array}{l}\text { Specific } \\
\text { hypothesis }\end{array}$ & $\begin{array}{l}\text { General } \\
\text { objective }\end{array}$ & $\begin{array}{l}\text { Specific } \\
\text { objectives }\end{array}$ \\
\hline \multirow{3}{*}{$\begin{array}{l}\text { Design of a } \\
\text { proposal for } \\
\text { improving the } \\
\text { organizational } \\
\text { culture in } \\
\text { terms of } \\
\text { management } \\
\text { skills in the } \\
\text { Technological } \\
\text { Institute of } \\
\text { Lazaro } \\
\text { Cardenas. }\end{array}$} & \multirow{3}{*}{$\begin{array}{l}\text { What are the } \\
\text { dimensions of } \\
\text { the design of } \\
\text { a proposal for } \\
\text { improving the } \\
\text { organizational } \\
\text { culture of the } \\
\text { Technological } \\
\text { Institute of } \\
\text { Lázaro } \\
\text { Cárdenas, } \\
\text { depending on } \\
\text { the } \\
\text { managerial } \\
\text { skills? }\end{array}$} & $\begin{array}{l}\text { 1) What is the } \\
\text { leadership } \\
\text { style that } \\
\text { determines } \\
\text { the values of } \\
\text { organizational } \\
\text { culture in the } \\
\text { Technological } \\
\text { Institute of } \\
\text { Lazaro } \\
\text { Cardenas? }\end{array}$ & \multirow[t]{3}{*}{$\begin{array}{l}\text { Management } \\
\text { skills of an } \\
\text { organization } \\
\text { influence } \\
\text { their } \\
\text { organizational } \\
\text { culture. }\end{array}$} & $\begin{array}{l}\text { 1) Leadership } \\
\text { styles } \\
\text { influence } \\
\text { organizational } \\
\text { values at the } \\
\text { Technological } \\
\text { Institute of } \\
\text { Lazaro } \\
\text { Cardenas and } \\
\text { his }\end{array}$ & \multirow[t]{3}{*}{$\begin{array}{l}\text { Designing a } \\
\text { proposal for } \\
\text { improving the } \\
\text { organizational } \\
\text { culture of } \\
\text { technological } \\
\text { institute } \\
\text { Lazaro } \\
\text { Cardenas, } \\
\text { depending on } \\
\text { management } \\
\text { skills. }\end{array}$} & $\begin{array}{l}\text { 1) Analyze } \\
\text { what the } \\
\text { current } \\
\text { leadership } \\
\text { style in } \\
\text { Lazaro } \\
\text { Cardenas } \\
\text { institute of } \\
\text { technology } \\
\text { and its } \\
\text { influence on } \\
\text { organizational } \\
\text { values. }\end{array}$ \\
\hline & & $\begin{array}{l}\text { 2) What is the } \\
\text { influence of } \\
\text { attitudes that } \\
\text { determine } \\
\text { teamwork in } \\
\text { the } \\
\text { Technological } \\
\text { Institute of } \\
\text { Lazaro } \\
\text { Cardenas? }\end{array}$ & & $\begin{array}{l}\text { 2) The } \\
\text { attitudes of } \\
\text { workers in } \\
\text { the } \\
\text { technological } \\
\text { institute } \\
\text { determine } \\
\text { teamwork. }\end{array}$ & & $\begin{array}{l}\text { 2) Determine } \\
\text { the influence } \\
\text { of teamwork } \\
\text { in the } \\
\text { attitudes of } \\
\text { workers } \\
\text { Lazaro } \\
\text { Cardenas } \\
\text { Institute of } \\
\text { Technology. }\end{array}$ \\
\hline & & $\begin{array}{l}\text { 3) What is the } \\
\text { influence of } \\
\text { motivation on } \\
\text { behavior in } \\
\text { organizational } \\
\text { culture in the } \\
\text { Technological } \\
\text { Institute of } \\
\text { Lazarus } \\
\text { Cárdenas }\end{array}$ & & $\begin{array}{l}\text { 3) Motivation } \\
\text { influences the } \\
\text { behavior of } \\
\text { workers in } \\
\text { the } \\
\text { Technological } \\
\text { Institute of } \\
\text { Lazarus } \\
\text { Cardenas. }\end{array}$ & & $\begin{array}{l}\text { 3) To analyze } \\
\text { the influence } \\
\text { of motivation } \\
\text { on the } \\
\text { behavior of } \\
\text { workers in } \\
\text { the institute } \\
\text { of technology } \\
\text { Lazarus } \\
\text { Cardenas. }\end{array}$ \\
\hline
\end{tabular}

the degree of influence i.e. both managerial skills influence in shaping organizational culture see figure 3 


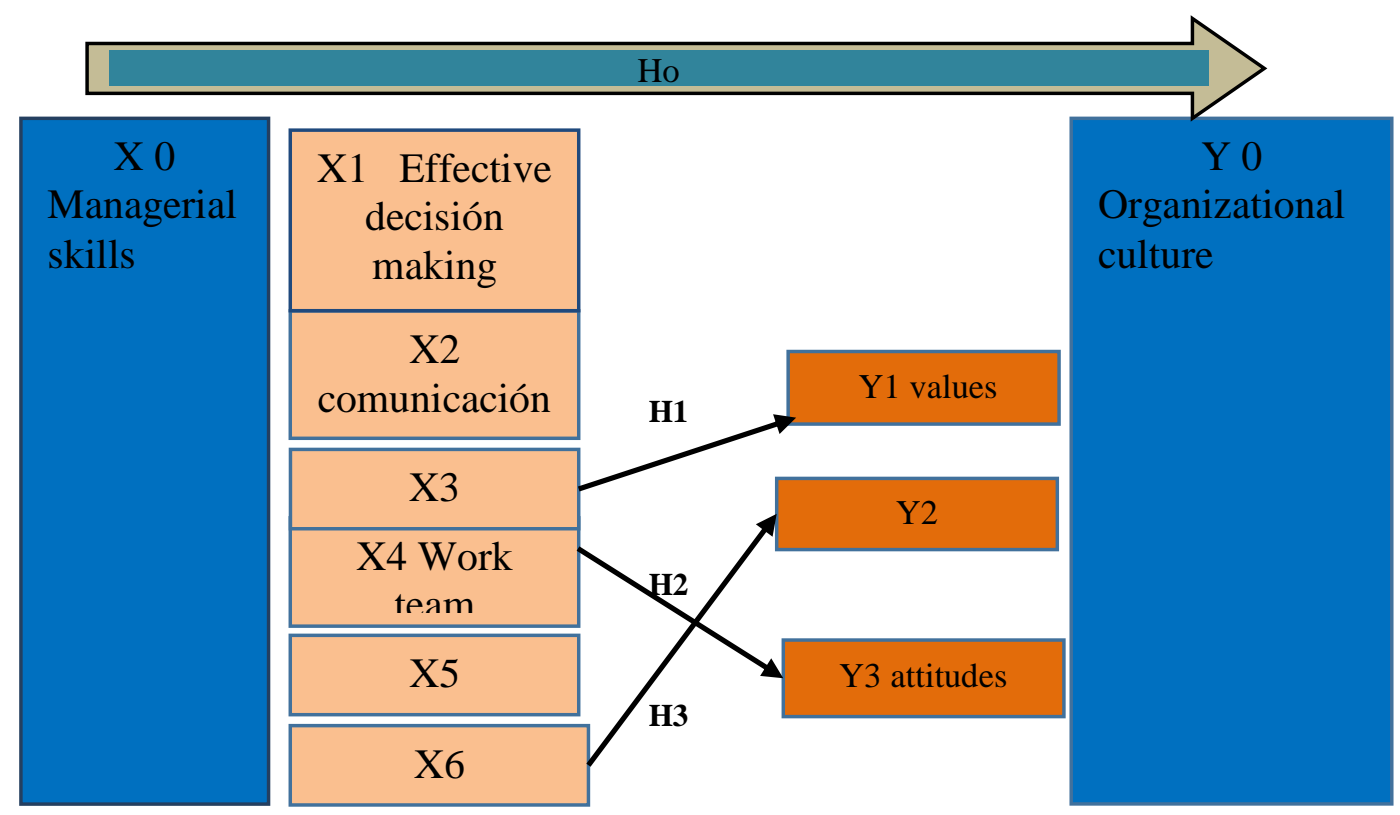

Figure 3. Research construct: Deployment of variables, dimensions and hypotheses.

Source: Authors.

\section{Research proposal}

\section{A.Consistency of the methodological design}

Table 5. Consistency of methodological design.

Source: Authors.

After it was conducted the reviewing of the theoretical development of this research. Management skills competencies are defined as: In business skills are considered one administration according to its capacity and ability to lead an organization toward predetermined goals. Guide, communication, direct, take decisions, negotiate and solve conflicts, are verbs that name actions of prime importance in any leadership role in any public or private organization (Madrigal, 2006).

The theoretical framework proposed for the variable of organizational culture by Schein (1992) says that within the corporate culture can find behaviors observed regularly in the relationship between individuals, such as the language used and rituals outside the deference and behavior, the rules developed in the working groups, those accepted by a company dominant values, the philosophy guiding the company policy regarding its employees and / or clients, the rules to advance in the company, the "threads" that a newly built must learn to manage to be accepted as a member, the environment or climate that is set in a company for the physical distribution of its members and how they relate to teeth or other third parties. 
Culture in organizations is the general guide of behavior, shared beliefs and values that members have in common (Shein, 1992). It is an imperative then that transformational leadership is exercised by managers in enterprises. They must be working to develop policies that encourage employees to develop their daily tasks. It is essential that the manager that has led to the working groups has this primary and fundamental skill.

\section{Conclusions}

Higher education is central to the development of a country, state or region, since it contributes to its growth through workforce. Educational institutions must be spaces of scientific theoretical knowledge but also should serve as integral forming of individuals creating in them a sense of integrity. Therefore institutions should be entities where a harmonious culture prevails among its members internally.

A.The management function is an important part because it rests the responsibility and authority exercised with parity which contributes to the achievement of organizational improvement, same as through it the fundamental decisions are made for the harmonious growth of the institution.

B.The organizational culture is essential, is therefore a key to achieving the goals and institutional development. Therefore, it is an imperative that each educational institution of higher level makes a diagnosis on the current status of its displayed organizational culture.

C.The corporate culture can be inferred from what people say, do and think within an organizational environment. Includes learning and transmitting knowledge, beliefs and behavior patterns over a period, which means it is a culture of fairly stable organization and does not change so fast.

D.The attitudes of performance are set properly for all those capacities that have individuals working in an organization. These capabilities are considered both personal and management skills that have the employees.

E.Determine a proposed improvement through practical and theoretical precepts to improve through strategic actions the organizational culture with the firm objective of achieving growth and institutional development, in which are reviewed motivation, leadership, teamwork, negotiation and decision making schemes prevailing in the institution in order to contribute to an improvement.

\section{References}

Aburto Pineda H (2011). Las Habilidades Directivas y su repercusión en el clima laboral (Tesis de doctorado, Instituto Politécnico Nacional).Recuperado de HYPERLINK "http://tesis" http://tesis ipn.mx/handle/12345678/11674/habilidades.dir.pdf

Cárdenas., I. T. (2007). Programa Institucional de Innovacion y Desarrollo 2006-2012. lazaro Cárdenas michoacan.: Direccion General de Educacion Superior Tecnológica.

Cardona, P. (1999). En busca de las Competencias Directivas. IESE - REVISTA DE ANTIGUOS ALUMNOS, 1,2 . 


\section{Journal of Social Sciences (COES\&RJ-JSS), 4(3), pp. 901-918}

Gordon, J. (1997). Comportamiento organizacional. Mexico: Prentice Hall.

Hellrigel D, J. S. (2002). Administracion un enfoque basado en competencias. Thomson.

Hofsted, G. (1999). Culturas y organizaciones. El software mental. Madrid: Alianza.

Jude A. Timothy, S. P. (Decimotercera edicion). Comportamiento Organizacional. Mèxico: Person.

Madrigal Torres, B. E. (2009). Habilidades directivas. Mexico: Mc Wraw Hill.

Ouchi, W. (1981). Teory Z: How American Bisness can meet the japanes Challeng. AdisonWesley.

Puga Villareal Julian, M. C. (2008). Competencias directivas en escenarios globales. Estudios Gerenciales.

Shein, E. (1992). Organitational Culture and Leadership. San Francisco: Jossey-Bass 2 da. Ed.

Villa, A. P. (2007). Aprendizaje basado en competencias: una propuesta para la evaluacion de las competencias genericas. Bilbao: Mensajero.

Whetten A. D., Cameron, S. (2011). Desarrollo de habilidades directivas. Mexico: Person 